\title{
Antipyrine clearance during occupational exposure to styrene
}

\author{
M DØSSING \\ From the Medical Department A, Division of Hepatology, Rigshospitalet, Copenhagen, DK-2100 Denmark
}

ABSTRACT Animal experiments have indicated that styrene, which is a widely used organic solvent, may induce the microsomal enzyme function of the liver. Thirteen workers with long-term exposure to styrene in a polyester plant were investigated. They worked at air concentrations about the maximal allowed time-weighted average concentration of styrene in most Western countries (50 $\mathrm{ppm})$. The clearance of antipyrine was determined from saliva concentrations before and after three weeks free of exposure and then again three weeks after returning to work. Thirteen matched controls were investigated with similar intervals and methods. No significant differences were found between the half life, apparent volume of distribution, or clearance of antipyrine either within the groups or between the groups. The data exclude (95\% confidence limit) the possibility that occupational exposure to styrene at concentrations about $50 \mathrm{ppm}$ stimulates the microsomal enzyme function of the liver to a degree compatible with an increase in antipyrine clearance of more than $2 \mathrm{ml} \times \min ^{-1}(3 \%)$. While the first antipyrine estimation was carried out under medical supervision, the workers themselves managed to perform the antipyrine test correctly after verbal and written instructions. This has broadened the application of the antipyrine test.

Most xenobiotics including drugs and industrial chemicals are metabolised by the microsomal enzyme system of the liver. Endogenous substances such as steroid hormones are also metabolised by this enzyme system. 12

Experimental studies have shown that styrene, a highly volatile and lipophilic organic solvent, is metabolised by the hepatic mixed oxidase system and stimulates the activity of the microsomal enzymes, including the site of its own metabolism. ${ }^{3}$ Studies concerning the inducing effect of exposure to styrene in man show conflicting results, however. ${ }^{45}$

The most widely used non-invasive quantitative assessment of the microsomal enzyme function in man is the antipyrine test. ${ }^{2}$ This test has the advantage of being relatively resistant to influence by alcohol consumption, ${ }^{67}$ while changes in antipyrine metabolism have been found in workers exposed to pesticides, ${ }^{8}$ polychlorinated biphenyls, ${ }^{9}$ waste anaesthetics, ${ }^{10}$ and lead. ${ }^{11}$ Recently an enhanced antipyrine biotransformation has been found in

Supported with grants from the Danish Working Environment Fund.

Received 14 January 1982

Accepted 6 May 1982 workers exposed to petroleum, which is a mixture of lipophilic hydrocarbons. ${ }^{12}$

The purpose of this study was to assess the hepatic microsomal enzyme function by measuring antipyrine clearance in man during occupational exposure to styrene, after three weeks free from exposure, and three weeks after returning to work.

\section{Material and methods}

A polyester plant where air analyses of styrene vapour were performed during the year before the study was investigated by the safety organisation in collaboration with the Technological Institution of Coppenhagen. The production operations and chemicals used have been essentially unchanged since the plant started 23 years ago.

Thirteen workers were exposed to styrene during the manufacture of polyester reinforced skylights. The polyester was mixed with styrene and a hardener. This mixture was poured on to a folio layer and then smoothed by hand-held aluminium scrapers. A layer of glass fibre was applied on the polyester mass and covered by folio. The margins of the product were sealed and finally formed on templets of different shapes. Small amounts of acetone were used to clean the tools. 
Air analyses of styrene and acetone had been performed by Dräger tubes ${ }^{13}$ or sampled on charcoal tubes and analysed by gas liquid chromatography ${ }^{14}$ during the year before the study. The samples had been collected during the different work operations in periods of 15-30 minutes and by sampling from the breathing zone during an entire working day (table 1).

A meeting with all 15 workers in the polyester production unit was arranged through the union by contacting the workers' safety delegate. The purpose and risks of the study were discussed with the workers and all gave informed consent.

Lifetime occupational histories of all subjects were obtained. The workers had been employed at the polyester plant for a median of nine years (range 1-23). Only one of the workers had previously been exposed to other chemical agents while working as a house carpenter (lacquers and glues). Two were skilled workers (the house carpenter and an electrician). The others were unskilled.

Age, sex, bodyweight, height, information about smoking habits, average daily alcohol consumption, and coffee/tea consumption are shown in table 2.

Daily alcohol consumption exceeding four drinks (about $50 \mathrm{~g}$ of ethanol) was established as an exclusion criteria. Two workers had a daily alcohol consumption of five and seven drinks, respectively. Nevertheless, all the workers participated in the study to avoid unnecessary antagonism; the data from the two heavy drinkers were omitted.

None was a vegetarian or regular consumer of charcoal broiled food known to influence the microsomal enzyme function. ${ }^{2}$ None was taking drugs regularly or had taken drugs during the last month before the study. Two occasionally took acetylsalicylic acid in moderate doses. None had previously suffered from allergic reactions or had previous or present kidney or liver disease.

Out of 48 control workers, none of whom was occupationally exposed to chemicals during daily work, 13 were selected with the closest match according to age, sex, cigarette and alcohol consumption, and education (skilled/unskilled worker). They were investigated similarly to the exposure group.

The initial investigation took place in the middle of the week before the summer vacation.

From venous blood samples serum alanine aminotransferase and alkaline phosphatases were investigated within four hours. A sample of serum was stored at $-20^{\circ} \mathrm{C}$ for two months before $\gamma$ glutamyl transpeptidase (s- $\gamma$ GT) was measured on a Rocke-kit based on the method by Rosalki and Rowe. ${ }^{16}$

\section{ANTIPYRINE TEST}

Salivary samples of at least $5 \mathrm{ml}$ were collected before and three, five, seven, 12, and 24 hours after taking $1 \mathrm{~g}$ antipyrine in $10 \%$ solution diluted with water. At least four hours had passed since the last meal.

The first administration of antipyrine and collection of a sample was performed under medical supervision at the plant. The workers performed the antipyrine test themselves after careful verbal and

Table 1 Air styrene concentrations sampled at a polyester plant near the breathing zone of the workers during different work operations. The air samples were collected on five working days during the year before the study

\begin{tabular}{llllll}
\hline Air concentration of styrene (ppm) & \multicolumn{1}{c}{} \\
\hline Month and year of measurement & May 1979 & July 1979 & October 1979 & April 1980 & June $1980^{*}$ \\
No of measurements & 24 & 10 & 32 & 32 & 4 \\
Air concentration of styrene in ppm & 50 & 35 & 49 & 35 & 11 \\
median (range) & $(10-100)$ & $(15-50)$ & $(15-70)$ & $(15-70)$ & $(8-36)$ \\
\hline
\end{tabular}

${ }^{*}$ Air concentrations of acetone: median 51 ppm (range $\left.45-70 \mathrm{ppm}\right)$.

Table 2 Age, sex, bodyweight, body height, average daily consumption of coffee/tea, alcohol, and cigarettes in 13 polystyrene workers occupationally exposed to styrene (exposure group) and 13 control workers (control group). All the values are given as the median (range in parentheses)

\begin{tabular}{|c|c|c|c|c|c|c|c|}
\hline & $\begin{array}{l}\text { Age } \\
\text { (years) }\end{array}$ & $\begin{array}{l}\text { Sex } \\
\text { (male/female) }\end{array}$ & $\begin{array}{l}\text { Bodyweight } \\
(\mathrm{kg})\end{array}$ & $\begin{array}{l}\text { Body height } \\
\text { (cm) }\end{array}$ & $\begin{array}{l}\text { Average daily } \\
\text { coffee/tea } \\
\text { consumption } \\
\text { (index*) }\end{array}$ & $\begin{array}{l}\text { Average daily } \\
\text { alcohol } \\
\text { consumption } \\
\text { (drinks) }\end{array}$ & $\begin{array}{l}\text { Average cigarette } \\
\text { consumption } \\
\text { (No/day) }\end{array}$ \\
\hline $\begin{array}{l}\text { Exposure group } \\
(n=13) \\
\text { Control group } \\
(n=13)\end{array}$ & $\begin{array}{l}32 \\
(17-57) \\
34 \\
(27-60)\end{array}$ & $\begin{array}{l}12 / 1 \\
12 / 1\end{array}$ & $\begin{array}{l}75 \\
(51-94) \\
72 \\
(48-98)\end{array}$ & $\begin{array}{l}176 \\
(161-184) \\
180 \\
(160-199)\end{array}$ & $\begin{array}{l}6 \\
(0-11) \\
6 \\
(0-23)\end{array}$ & $\begin{array}{l}2 \\
(0-4) \\
2 \\
(0-4)\end{array}$ & $\begin{array}{l}10 \\
(0-20) \\
10 \\
(0-30)\end{array}$ \\
\hline
\end{tabular}

${ }^{*}$ No of cups of coffee $+0.6 \times$ No of cups of tea. 15 
Table 3 Saliva antipyrine half life $\left(T^{1 / 2}\right)$, apparent volume of distribution $\left(a V_{D}\right)$, and clearance $\left(C l_{A P}\right)$ among 13 polyester workers (exposure group) determined during exposure, three weeks after cessation of exposure, and three weeks after resuming occupational exposure to styrene. Thirteen controls were investigated simultaneously. $S-\gamma G T$ estimated during exposure is also shown. All figures except s- $\gamma$ GT are given in mean values and $S D$ in parentheses

\begin{tabular}{|c|c|c|c|c|c|c|c|c|c|c|}
\hline & \multirow{2}{*}{$\begin{array}{l}s-\gamma G T \\
\text { normal } \\
<40 U \times 1 \\
\text { median } \\
\text { (range) }\end{array}$} & \multicolumn{3}{|c|}{ During exposure } & \multicolumn{3}{|c|}{ After exposure } & \multicolumn{3}{|c|}{ During exposure } \\
\hline & & ${ }^{-1} T^{1 / 2}$ & $\underset{(I)}{a V D}$ & $\begin{array}{l}C l_{A P} \\
\left(m l \times \min ^{-1}\right.\end{array}$ & $\begin{array}{l}T 1 / 2 \\
1)(h)\end{array}$ & $\underset{(I)}{a V_{D}}$ & $\begin{array}{l}C l_{A P} \\
\left(m l \times \min ^{-1}\right.\end{array}$ & $\begin{array}{l}T 1 / 2 \\
\text { l)(h) }\end{array}$ & $\underset{(I)}{a V D}$ & $\begin{array}{l}C l_{A P} \\
\left(m l \times \min ^{-1}\right)\end{array}$ \\
\hline \multirow{2}{*}{$\begin{array}{l}\text { Exposure } \\
\text { group } \\
\text { (n=13) } \\
\text { Control } \\
\text { group } \\
(n=13)\end{array}$} & 21 & $\begin{array}{l}8 \cdot 7 \\
(2 \cdot 6)\end{array}$ & $\begin{array}{l}45 \cdot 8 \\
(8 \cdot 2)\end{array}$ & $\begin{array}{c}60 \cdot 0 \\
(14 \cdot 7)\end{array}$ & $\begin{array}{c}9 \cdot 6 \\
(3 \cdot 2)\end{array}$ & $\begin{array}{c}48 \cdot 8 \\
(11.6)\end{array}$ & $\begin{array}{c}64 \cdot 2 \\
(21 \cdot 3)\end{array}$ & $\begin{array}{c}9.4 \\
(1.8)\end{array}$ & $\begin{array}{c}51 \cdot 0 \\
(16 \cdot 4)\end{array}$ & $\begin{array}{l}62 \cdot 6 \\
(18 \cdot 7)\end{array}$ \\
\hline & $\begin{array}{l}19 \\
(10-93)\end{array}$ & $\begin{array}{l}10 \cdot 3 \\
(3 \cdot 0)\end{array}$ & $\begin{array}{l}52 \cdot 0 \\
(6 \cdot 3)\end{array}$ & $\begin{array}{c}59.9 \\
(19.7)\end{array}$ & $\begin{array}{l}11.6 \\
(4.9)\end{array}$ & $\begin{array}{c}48.6 \\
(11.9)\end{array}$ & $\begin{array}{c}54 \cdot 7 \\
(16 \cdot 5)\end{array}$ & $\begin{array}{l}10 \cdot 4 \\
(4 \cdot 1)\end{array}$ & $\begin{array}{l}49.8 \\
(9 \cdot 1)\end{array}$ & $\begin{array}{c}59.4 \\
(19.5)\end{array}$ \\
\hline
\end{tabular}

written instruction. The antipyrine clearance was measured after three weeks of summer vacation and three weeks after returning to work. If the workers were in doubt they could contact the laboratory technician or me by phone.

The samples of saliva were kept at $4^{\circ} \mathrm{C}$ until delivered to the laboratory, where the samples were stored at $-20^{\circ} \mathrm{C}$ until analysed in duplicate from one month to four months later using gas liquid chromatography. 17

Before the study it had been shown that samples of saliva could be kept at room temperature for at least 14 days or kept frozen at $-20^{\circ} \mathrm{C}$ for six months without any change in the concentration of antipyrine beyond the analytical precision of $1-4 \%$.

Antipyrine half life $\left(T^{1 / 2}\right)$ was calculated by least squared regression analyses of saliva log concentration with respect to time assuming complete and rapid absorption and distribution of antipyrine. The apparent volume of distribution $\left(\mathrm{aV}_{\mathrm{D}}\right)$ was estimated as the dose divided by the extrapolated saliva concentration at time zero. Clearance was calculated as $\mathrm{V}_{\mathrm{D}} \times \frac{\operatorname{In} 2}{\mathrm{~T}^{1} / 2}$.

Differences between means were compared with a paired or unpaired $t$-test, when testing within groups or between groups, respectively. Accordingly a Wilcoxon rank sum test of paired and non-paired data was used when evaluating non-normally distributed data: $p<0.05$ was considered statistically significant.

\section{Results}

There was no difference between the half life, apparent volume of distribution, or clearance of antipyrine in saliva estimated during exposure to styrene either after three weeks free of exposure or three weeks after resuming work $(p>0 \cdot 3$, paired test).

Furthermore, no differences were found in the control group between the three antipyrine measure- ments performed with similar time intervals (table 3 ). $\mathrm{Cl}_{\mathrm{AP}} \mathrm{aV}_{\mathrm{D}}$ and $\mathrm{T}^{1 / 2}$ of the exposure group and control group did not differ significantly.

Results of linear regression and correlation analyses of the log antipyrine concentration versus time curves showed no difference between the correlation coefficients $\left(\mathrm{r}^{2}\right)$ of the antipyrine decay in saliva estimated at the three occasions (median $\mathrm{r}^{2}$ : 0.98; $0.96 ; 0.98$ and $0.99 ; 0.99 ; 0.96$ for the exposed and control subjects, respectively). The corresponding figures for the residual variances of the analyses were $4.1 \% ; 5.5 \% ; 4.2 \%$ and $6.5 \% ; 4.8 \%$; and $6.5 \%$, respectively.

The interindividual variation in $\mathrm{Cl}_{\mathrm{AP}}$ calculated as the percentage deviation from the mean of each of the three measurements in both groups separately gave a median of $18.2 \%$ (range $0.3-43.0 \%$ ) for the exposure group, and $21 \cdot 0 \%(0 \cdot 5-86 \cdot 1 \%)$ for the control group. The intraindividual deviation from the mean of the three measurements in each individual was median $8.9 \%$ (range $0.5-44.8 \%$ ) and $10 \%(0.0-43.7 \%)$ in the exposure group and control group, respectively.

Table 2 shows that the two groups were comparable with respect to smoking and drinking habits. The s-alkaline phosphatase, s-alanine aminotransferase, and s- $\gamma$ GT sampled simultaneously with the first antipyrine measurement did not differ significantly between the groups.

There was no significant correlation between s- $\gamma$ GT and the alcohol consumption, neither within the groups separately nor with all the subjects considered.

\section{Discussion}

No difference was found in the antipyrine clearance after discontinuation of long-term occupational exposure to styrene for three weeks among 13 polyester workers, indicating that occupational styrene exposure does not induce the microsomal enzyme system. This is supported by the lack of difference 
between $\mathrm{Cl}_{\mathrm{AP}}$ of the styrene workers and that of a matched control group investigated with similar time intervals. Moreover the s- $y$ GT level of the polyester workers was similar to that of the control group and unrelated to alcohol consumption.

In a previous study a higher level of s- $y$ GT was recorded among workers exposed to a vapour concentration of several hundred ppm styrene compared with a normal level found in a group exposed to styrene concentrations similar to the exposure level of the actual plant in this study. No control group was investigated and s- $\gamma$ GT was the only measure of microsomal enzyme function performed.

In another study of workers occupationally exposed to about $100 \mathrm{ppm}$ styrene the urinary excretion of glucaric acid and s- $\gamma$ GT level in plasma were measured. The conclusion that styrene does not induce the microsomal enzyme function is weakened by the omission of a suitable control group and the lack of appropriate measurements during exposurefree periods. ${ }^{5}$

An inducing effect of styrene has been shown on some of the microsomal enzymes in animal experiments. ${ }^{3} 17$ The dose of styrene used in these studies was considerably higher than that encountered in industry, and styrene was administered for only a few days.

Simultaneous exposure to styrene and acetone have shown an additive effect of the inducing properties of the two solvents in animal experiments. ${ }^{18}$ The exposure level of acetone used in that study, however, far exceeds that of the exposed workers in the present study, which was only $1 / 20$ of the maximal allowed time weighted average concentration of acetone (table 1).

The workers in this study had been exposed to styrene at a level about the maximal allowed time weighted average concentration in most Western countries $(50 \mathrm{ppm})$. The exposure level has probably been quite constant through the years, since the process and materials used have been virtually unchanged on the polyester plant.

The lack of change in antipyrine clearance $\left(\mathrm{Cl}_{\mathrm{AP}}\right)$ among those exposed to styrene could be due to the condition of the study. Three weeks could be too short a period for the microsomal enzyme system function to return to normal. In man, however, styrene has a half life of a few hours in blood and one to two days in adipose tissue. 1920 One week after cessation of exposure to $50 \mathrm{ppm}$ styrene it is unlikely that biologically important amounts of styrene remain in the human body. According to other studies the change in $\mathrm{Cl}_{\mathrm{AP}}$ induced by environmental factors returns to pre-exposure levels within 7-10 days. ${ }^{21-25}$ Thus three weeks should suffice for the microsomal enzyme system to return to normal. The possibility that $\mathrm{Cl}_{\mathrm{AP}}$ among the exposed workers could remain induced during summer vacations is also contradicted by the lack of difference between the $\mathrm{Cl}_{\mathrm{AP}}$ of the exposure group and of the control group.

The equally high correlation coefficients and low residual variation of all regression and correlation analyses of the log antipyrine on time curves indicate that the workers managed to take antipyrine and collect saliva correctly. This is supported by the magnitude of the estimated inter- and intraindividual differences in $\mathrm{Cl}_{\mathrm{AP}}$ which is close to the results of recent studies, where, as in the present study, no attempt was made to control the life styles of the subjects concerned. ${ }^{26} 27$

In conclusion, this study excludes $(95 \%$ confidence limit) the possibility that occupational exposure to styrene at concentrations about $50 \mathrm{ppm}$ induces the microsomal enzyme function to a degree compatible with an increase in antipyrine clearance of more than $2 \mathrm{ml} / \mathrm{min}(3 \%)$.

\section{References}

1 Burke DM. Cytochrome P-450: a pharmacological necessity or a biochemical curiosity? Biochem Pharmacol 1981;30:181-7.

2 Vesell ES. The antipyrine test in clinical pharmacology: conceptions and misconceptions. Clin Pharmacol Ther 1979;26: 275-86.

3 Parkki MG, Marniemi J, Vainio H. Action of styrene and its metabolites styrene oxide and styrene glycol on activities of xenobiotic biotransformation enzymes in rat liver in vivo. Toxicol Appl Pharmacol 1976;38:59-70.

4 Lorimer WV, Lilis R, Nicolson WJ, et al. Clinical studies of styrene workers: initial findings. Environ Health Perspect 1976;17:17181.

s Holtz P, Guillemin MP, Lab M. Study of some hepatic effects (induction and toxicity) caused by occupational exposure to styrene in the polyester industry. Scand $J$ Work Environ Health 1980;6:206-15.

6 Dossing M, Andreasen PB. Ethanol and antipyrine clearance. Clin Pharmacol Ther 1981;29:101-4.

7 Vestal RE, Norris AH, Tobin JD, Cohan BH, Shock NW, Andres R. Antipyrine metabolism in man: influence of age, alcohol, caffeine and smoking. Clin Pharmacol Ther 1975;18:425-32.

${ }^{8}$ Kolmodin B, Azarnoff DL, Sjöqvist F. Effect of environmental factors on drug metabolism: decreased plasma half life of antipyrine in workers exposed to chlorinated hydrocarbon insecticides. Clin Pharmacol Ther 1969;10:638-42.

- Alvares AP. Fishbein A, Anderson KE. Kappas AK. Alterations in drug metabolism in workers exposed to polychlorinated biphenyls. Clin Pharmacol Ther 1977;22:140-6.

10 Duvaldestin P. Mazze RI, Nivoche Y, Desmonts JM. Occupational exposure to halothane results in enzyme induction in anesthetists. Anesthesiology 1981;54:57-60.

11 Alvares AP, Fishbein A, Sassa S, Anderson KE, Kappas A. Lead intoxication: effect in cytochrome P-450-mediated hepatic oxidations. Clin Pharmacol Ther 1976;19:183-90.

12 Harman AW, Frewin DB, Priestly BG. Induction of microsomal drug metabolism in man and in rat by exposure to petroleum. $\mathrm{Br}$ J Ind Med 1981;38:91-7.

${ }^{13}$ Leichnitz K. Prüfrörchen-Tachenbuch: Luftuntersuchungen und technique Gasanalyse mit Dräger rörchen. 1976.

14 National Institute for Occupational Safety and Health. Manual of analytical methods. 2nd ed. Washington: US Department of 
Health, Education and Wellfare, 1977. (DHEW publication No 77-157-6, method No 127.)

is Nagy M. Caffeine content of beverages and chocolate. JAMA 1974;229:337.

${ }^{16}$ Rosalki SB, Rowe JA. Gamma-glutamyl-transpeptidase activity of human seminal fluid. Lancet 1973;i:223-4.

17 Prescott LF, Adhpon-Yamoah KK, Roberts E. Rapid gas-liquid chromatographic estimation of antipyrine in plasma. $J$ Pharm Pharmacol 1973;25:205-7.

18 Sandell J, Marniemi J, Parrki MG, Aitio A. Effects of inhalation and cutaneous exposure to styrene on drug metabolizing enzymes in the rat. In: Fouts JR, Gut I, eds. Industrial and environmental xenobiotics. Amsterdam: Exerpta Medica, 1978: $177-9$.

19 Vainio H, Zitting A. Interaction of styrene and acetone with drug biotransformation enzymes in rat liver. Scand J Work Environ Health 1978;4, suppl 2:47-52.

${ }^{20}$ Ramsey JC, Young JD. Pharmacokinetics of inhaled styrene in rat and humans. Scand J Work Environ Health 1978;4, suppl 2:8491.
${ }^{21}$ Engström J: Styrene in subcutaneous adipose tissue after experimental and industrial exposure. Scand $J$ Work Environ Health 1978;4, suppl 2:119-20.

22 Walter E, Staiger C, deVries J, Zimmermann R, Weber E. Induction of drug metabolizing enzymes by sulfinpyrazone. Eur J Clin Pharmacol 1981;19:353-8.

${ }^{23}$ Lai AA, Levy RH, Cutler RE. Time-course of interaction between carbamazepine and clonazepam in normal man. Clin Pharmacol Ther 1978;24:316-23.

24 Farrel GC, Cooksley WGE, Powell LW. Enhancement of hepatic drug metabolism by glutethimide in patients with liver disease. Eur J Clin Pharmacol 1979;16:113-7.

${ }^{25}$ Ballinger B, Browning M, O'Malley K, Stevenson IH. Drugmetabolizing capacity in states of drug dependence and withdrawal. Br J Pharmacol 1972;45:638-43.

26 Alvares AP. Kappas A. Eiseman JL, et al. Intraindividual variation in drug disposition. Clin Pharmacol Ther 1979;26:40719.

${ }^{27}$ Riester EF, Pantuck EJ, Pantuck CB, et al. Antipyrene metabolism during the menstrual cycle. Clin Pharmacol Ther 1980;28:384-91. 